いわし，あじ，かれいなどの灰分中のガリウム含量は，きわめ て小さく $10^{-5} \%$ あるいはそれ以下の低值を示す。海藻中のガリ ウムも少なく, 表 3 に示したように $0.5 \times 10^{-5} \sim 1.2 \times 10^{-4} \%$ の 籁囲にある。海藻 4 種の中ではあらめ, こんぶ，わかめにくらべ て，ひじきのガリウム含量が大きい。

海産植物と琵琶湖座の藻を比較すると, やはり陸水産藻類の方 がわずかではあるがガリウム量が大きいようである。

\section{2 缶石, コーラルサンドのガリウム含量}

午石, コーラルサンドのガリウム含量はきわめて小さく $10^{-5}$ 以下である。

表4 亿示した任石試料において番号 18, 19 の試料は軍艦蒸化 器内で生成したもので陸の影響は少ないものと考えられる。試料 番号 20〜23 の試料は海水が塩田を経たカン水から生成した缶石 で土垻の影䍌を受けている可能性がある。試料番号 24 の試料は さらに土塭の影響をうけやすい環境で生成したものである。表 4 から明らかなように, 試料番号 24 のガリウム含量が他の 6 個の 試料比較し大きいのは, 上䀶から由来したガリウムと考えて差 し支えないであろう。したがって海水に由来する午石中のガリウ ム含量は大約 $10^{-5} \%$ 以下と考劣られる。

また表 5 に示すように，コーラルサンド中のガリウム含量む小 さい。番号 25'，26'，29' は試料を $5 \mathrm{~g}$ 採取して（B）法により 共沈浱縮後定量した值である。コーラルサンド中のガリウム合量 はほほ $10^{-6 \%}$ 程度である。

任石, コーラルサンドはいずれもカルシウム, マグネシウムの 硫酸塭または炭酸塩が主成分であって，これらの試料がガリウム をほとんど含まないことは，さきに報告した岩石中，石灰岩がガ リウム含量のきわめて小さい事実 ${ }^{3)}$ とよく一致する*1。このこと はカルシウム, マグネシウムの硫酸塩あるいは炭酸塩にはガリウ ムが濃縮され難いことを示すものと考えられる。

*1 石灭岩のほかマグネサイト中にるガリウムははとんど含まれていない.

\section{3 海底土のガリウム含量}

海底土は陸与の岩石（とくに火成岩）と同程度のガリウムを含 有している。表 6 亿示す 11 個の試料において最低 $1.2 \times 10^{-8} \%$, 最高 $2.0 \times 10^{-8} \%$ であり, 平均 $1.6_{6} \times 10^{-8}$ である。この平均值 はさきに報告した火成岩の平均ガリウム含量 $1.6 \times 10^{-8} \%$ とよ く一致している。また表 6 からわかるように陸土である黄土およ び，琵琶湖の底土などと比較しても海底土中のガりウム含量には 大きな差は認められない。

著者らが入手し得た海緑石試料は海底土のガリウム含量と同程 度あるいはそれ以下であり，海水中のガリウムがとくにいちじる しく海緑石に浱縮されるという傾向はない。

\section{4 海水および苦汁のガリゥム含业}

生苦汁試料 2 個についてガリウム量を（B）法により測定した 結果, いずれの試料にもガリウムは認められず海水濃縮過程にお いてガリウムは苦汁へはほとんど移行しないことを示す。

和歌山県白浜三段壁沖 3 マイルおよび舞鶴沖で採取した口過海 水（東洋汇紙 No. 7 で口過）を用い，共沈郕として A1 ${ }^{3+} 200$ $\mathrm{mg}$ を添加，（B）法によりガリウム量を求めた結果を表 7 試料番 号 45〜47 に示した。著者らの得た結果は 0.02 および $0.01_{5} \mu \mathrm{g}$ $\mathrm{Ga} / l$ で Culkin, Riley の值 $0.03 \mu \mathrm{g} \mathrm{Ga} / l$ とよく一致してい る。試料番号 46 に示した数值は原海水 $20 l$ をロ過した口紙拉 よび口紙上の残留物を白金ルツボ中で灰化し（A）法によりガリ ウムを定量した結果である。すなわち $20 l$ の海水中の浮游物中 にはガリウムは認められない。

同様の方法により琵琶湖の湖水についてガリウムを測定した結 果は $0.03_{8} \mu \mathrm{g} \mathrm{Ga} / l$ なる值であった。しかし湖水の口過残留物 中には試料番号 51 に示すように $0.6 \mu \mathrm{g} \mathrm{Ga} / 20 l$ のガリウムが 含まれ，口過水中の量にほほ等しい。この口過残留物のほとえど 大部分は泥土の浮游混溞成分らしい（濁度 4 )。

(1959 年 4 月, 日本化学会第 12 年会講演)

\title{
玉川温泉大ブキ No. 4 噴気孔ガスの放射性成分含有量の変化*1
}

(昭和 36 年 1 月 24 日受理)

鎌田政明†

強酸性宗であり，故射性温宗沈殷物を産出するので有名な秋田県玉川温泉の一噴気孔ガスについて 1952 年以降その放射性成分 含有量を研究した。その絬果との噴気孔ガスのトロン含有量が本邦での最大級の值を示したとと,トロンとラドンの量比は最大級

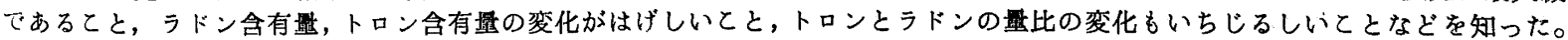
ての変化は 1 日のうちに起るとともある。1960年までの測定值の範团は, ラドン含有量 $17 \sim 118 \times 10^{-10} \mathrm{curie} \mathrm{Rn} / l\left(\mathrm{NTP}, \mathrm{H}_{2} \mathrm{O}\right.$

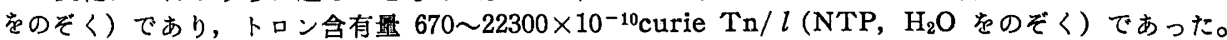

トロンとラドンの盤比は 35〜490(curie 比) で, Tn/Rn はとさにいちじるしく大きいが，いちじるしく変化するととがあり， 変化の模栚はきわめて不規則であるととがわかった。

とのようにトロン含有盟の大きいとと，Tn/Rn の大きいとと；それらの変化がいちじるしいとと，ラトン含有量の変化もいち しるしいととなどの原因についていろいろ吟味した結果,

（1）ラドン，トロンの供給源は比較的浅いととろ，すなわち地表近くにあるとと，

（2）供給源中のラジウム，トリウムXの含有量はかなり大きいが，分布が同所的であり，集中的であること，

を推定した。この結果，とくにガスのトロン含有量が大きく，したがって Tn/Rnも大きいが，ての噴気孔の噴出状態が変化し やすいという性資と（2）で推定した供給源のありかたが関係して, トロン, ラドンの各含有量, トロンとラドンの量比にいちじ るしい変化が扣てるととなどを綃論した。

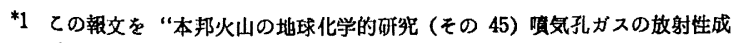
分 (第 5 報)”とする。 


\section{1 緒言}

前報1で箱根大湧谷坊主地獄の嘖気孔ガスの放射性成分含有量 の変化を利用して,その供給带の位置およびその中でのラジウム, トリウムXの分布状態を推定し, 群発地震のあった前後の変化の 原因を考察した。そのさいのべたように，1959 年 12 月の大きな 変化の前後ではラドン, トロン両成分ともにその含有量があまり 変化しないのである。

しかし箱根大湧谷の嗝気孔ガスのラドン含有量, とくにトロン 含有量はあまり大きいとはいえず, $T n / R n$ む貲気孔ガスとして は小さい方である。また供給帯のなかでのラジウム，もしくはト リウム $\mathrm{X}$ の分布状態は比較的分散的と推定したのであるが，それ を裹うけるように箱根大湧谷には放射性温泉沈殿物はまだみいだ されていない。

さて強放射能泉の場合ではあるが，ラドン含有量の多いものに は温泉水中のラドン含有量がいちじるしく変化する例が知られて (る22)。このような強放射能泉の湧出孔付近には，温泉水中のラ ドンの供給源として考えられるラジウムなどをふくむ放射性温泉 沈殿物がみいだされることが多く, 含有量が变化する見象に対し て，このような供給源層を通過する時間の変化によるという説 明い，異なった経路を通過するためであるという説明2)，ラドンが 地表から放散する割合が変化して温泉水中に異なった割合ではい ってくるためだという説明3)5), 温泉ガスと温泉水との量比の变化 にもとつくくをする説明るなど，各種の議論が試みられてきた。

貲気孔についてこれと類似した性格をむつものをあげるとする ならば, ラジウム, トリウム Xの多量を含む放射性温泉沈殿物を 産出するので著名な秋田県玉川温泉の大ブキより下流の貲気孔を おいてほかにないようである*2。

すでに著者らによって大ブキより下流の，小ブキの刘岸にある 一貲気孔が，あるとき $\mathrm{Tn} / \mathrm{Rn}$ の本邦最高值を示したことが明ら かにされている6゙。をこの試料のトロンの含有量は本邦の㗂気 孔ガス中では最大級》のものである。

このように箱根とは対照的な本試料の放射性成分含有量の变化 の性格をしらべることは，一般の噴気孔ガスの放射性成分の供給 源を考察するためにる有益であると思われるので, 1952 年以降 1960年までの間, 少なくとも 1 年間 1 回の調查を行なってきた。

\section{2 研 究 方 法}

\section{1 試料およびその探取方法}

試料としたもものは小ブキの対岸にある小さな吵気孔帛で，湯川 の岸にあり，湯川の水位の変化によってときには湯川の熱水の中 から，あるいは水際すれすれに噴出している。嘳出状態はかなり

1）的報（第 4 報），团，日化 82，1008 (1961).

2) K. Kuroda, Bull. Chem. Soc. Japan 19, 33 (1944); 黒田, 䟧( 化学の研究 3, 29 (1948)

3) 岩崎, 化学の研究 8, 1 (1950).

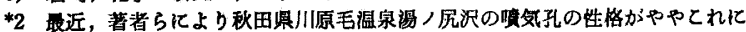
頪似するととがみいた゚されている; 踖田, 岩绮, 小沉，吉田，日本化学会地 玻学討調会䍀湠 (1960).

4) R. E. Belin, Geochimica et Cosmochimica Acta 16, 181 (1959)

5) K. Kikkawa, Japanese Journal of Geophysics 1, 1 (1954).

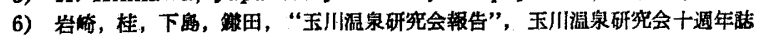
p. 141 (1954)

7) I. Iwasaki, T. Katsura, H. Shimojima, M. Kamada, Bulletin Volcanologigue, Série II, Tome XVI, 103 (1956)

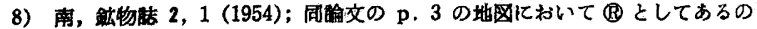
が小ブキである.
变化をすることがあったが，全般的に弱くなり，1960 年 10 月に はほとんど消滅に近い状態であった。

短時間の間に, 温度はそう变わらないのに水蒸気の㓶合がいち ビるしく增したりしたこともあった。本試料の近くにはかって間 ケツ泉が存在していたということであるす。ともかく，噴出状態 の変化がはげしいことはたしかであったが，ある周期をるって変 化したというようなことはなかった。

試料の採取法は，嗿出状態が大体に拈いて熱水中少らであり， 大湧谷のものと同様であったからそれに準じた方法を用いた1。

\section{2 ラドンおよびトロンの測定方法}

大体既報110)とおなじである。とくにこの試料では, Tn/Rn五 いちじるしく大きいので，感度を可変とする泉效計（ラドン媩） を考案し11)，使用した。既報したガス中から ThBを捕集するう 法も1ときどき使用した。ThB は大量に捕集でき, 捕集後 8 時 間後の放射能の減衰は, 半減期 10.6 時間にしたがい, ThB で あることを容易に確認しえた。

\section{3 カスの主化学成分の分析法}

既報 ${ }^{10)}$ と同様である。

\section{3 研 究 結 果}

表 1 亿 1952 年 10 月以降, 1960 年 10 月までの測定值を示 す。少なくとも年 1 回の測定值がある。ラドン含有量は curie $\mathrm{Rn} / l$ (NTP, $\mathrm{H}_{2} \mathrm{O}$ をのぞく) で示し*3, トロン含有量も curie $\mathrm{Tn} / l\left(\mathrm{NTP}, \mathrm{H}_{2} \mathrm{O}\right.$ をの奖く) で衣わした*4。Tn/Rn は curie 此で示した。

主化学成分の組成もときどき変化したが，放射性成分含有量の 変化に対応して変化したものはほとんどなかった。ここには版射 性成分含有量と比較的関係のありそうな $\mathrm{R}$ (ガスのうち $\mathrm{SO}_{2}$, $\mathrm{H}_{2} \mathrm{~S}, \mathrm{CO}_{2}$ などの酸性ガスを除いた残りの成分）の vol\%だけを 示しておいた。

\section{4 考察}

測定値をみると

（1）トロン含有量がきわめて大きい值を示したことがある。 この值は本邦の貲気孔ガスとしては最大級のものである*5。

（2）トロンとラドンの量比もきわめて大きい值を示したこと がある。もっとも小さな值を宋した場合でも一般の貲気孔ガスよ りはるかに大きい*。

(3) ラドン含有量, トロン含有量が短時間のあいだにいちじ るしく変化する。しかしこの場合 Tn/Rnの変化の幅は，それぞ れの変化の幅よりいくらか小さい。またラドン含有量の変化の幅 は, トロン含有量の変化の幅にくらべて全体としていくらか小さ W。

（4）逆に 1 日中のラドン含有量, トロン含有量, $\mathrm{Tn} / \mathrm{Rn}$ が あまり変化しない場合もある。

9) 三裸，日化 59, 178 (1938).

10）鉷田，日化 82，1005 (1961)

11) 銤田, 分析化学 5, 709 (1956)

*3 ラドンの 1 mache $=3.64 \times 10^{-10}$ curie $\mathrm{Rn} / l$.

*4 トロンの 1 mache については近似的には 1 mache $=3.18 \times 10^{-10}$ curie Tn/l (1) と考えてよい.ただしててで ThA なふくめいでトンの

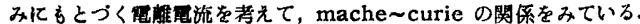

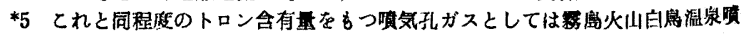
気孔群の一㥼料がある(続報する).

*6一般の德気孔ガスでての此の值は大きくても〜40にする゙い， 
表１ 1 玉川温泉大ブキ No. 4 噴気执ガスの放射性成分含有量の変化

測定年月日 時分 $\quad$ 温度

'52.10.18

'53.10.10

'54.10. $3 \quad 14.22$

14.39

'54.10. $4 \quad 12.10$

13.10

14.10

15.10

16.10

'54.10. $5 \quad 10.49$

11.51

12.22

13.54

22.17

'54.10. $6 \quad 10.06$

11.05

11.15

16.50

'55.10. $9 \quad 10.09$

12.46

14.56

16.04

16.33

16.47

'55.10.10

13.35

14.39 98

$15.47 \quad 98$

17.01

'56.10. 2

'56.10.11 10.25

10.52

11.02

'57. $7.22 \quad 8.52$

9.50

10.50

'57. $7.23 \quad 14.49$

15.19

'58.10.15 14.30

20.30

'59.10. 123.30

'59.10. $2 \quad 14.17$

14.35

'60. $7.31 \quad 8.55$

9.05

9.20

16.10

16.25

'60.10.10 17.25

\begin{tabular}{|c|c|}
\hline $\operatorname{Rn}$ 含有量 & "Tn 含有量 \\
\hline 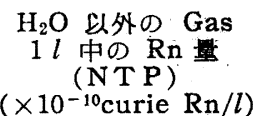 & $\begin{array}{c}\mathrm{H}_{2} \mathrm{O} \text { 以外の } \mathrm{Gas} \\
1 l \text { 中 } \\
\text { (NT T P }) \\
\left(\times 10^{-10} \text { curie } \mathrm{Tn} / l\right) \\
\end{array}$ \\
\hline
\end{tabular}

94

96

95

93

98

94.5

95.5

64

19

17

18.4

48

40

31

20.2

37

79.3

43.2

48

19.8

17.0

90

48

48

37

46

32.8

59

54.6

22.8

23.6

54.6

28.2

23.0

23.0

34.3

92

\begin{abstract}
4580
670
1780

2000

6610

6650

5150

9600

9730

13900

9480

15700

5310

4040

19100

16900

17800

22300
\end{abstract}

-

4670

4550

4450

4420

4230

4200

-

3430

-

2450

3720

$3370 \sim 3820$

5310

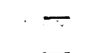

-

1370

4130

-

4450

$\begin{array}{cc}\mathrm{Tn} / \mathrm{Rn} & \mathbf{R} \\ \text { curie 比 } & \text { (vol\%) }\end{array}$

䚚 考

72

35

35

105$$
\begin{aligned}
& 108 \\
& 138
\end{aligned}
$$

166

166

480

263

$$
175
$$

220

327

270

237

400

350

480

490

-

-

-

210
190

$$
-
$$

$$
158
$$$$
190
$$$$
184
$$$$
122
$$$$
\text { 258 }
$$$$
174
$$$$
\text { - }
$$$$
59
$$$$
63
$$$$
83
$$$$
104
$$$$
\text { - }
$$$$
\text { - }
$$$$
\text { - }
$$

25.8

52

52

53

56

83
などの傾向が明らかであり, 箱根大湧谷の変化が群発地震が関 係したと思われる 1 回きりで，その前後ではほぼ一定であうたの に刘し，まったく刘照的な性質があることがわかる。ちょうど強 放射能泉でラドン含有量がいちじるしく変化する性質と同様であ る23)。

このような性質があらわれる原因について考えるには，やはり ラドン，トロンの佧給源がどのようなものであるかという点から
考えていかねばならない。

ここでみているのは $C_{\mathrm{N}}\left(\mathrm{NTP}, \mathrm{H}_{2} \mathrm{O}\right.$ をのぞいたもの) である が,いま

$$
C_{\mathrm{N}}=K\left[\frac{Q_{\mathrm{BO}}}{M_{\mathrm{T}}}\right] \quad K=\text { 定数 }
$$

なる関係があるとし ${ }^{122}, \frac{Q_{\mathrm{BO}}}{M_{\mathrm{T}}}$ について一般的に考えてみる。

12) 鏁田, 日化 82, 1000 (1961). 


$$
\frac{Q_{\mathrm{BO}}}{M_{\mathrm{T}}}=\frac{(1-\alpha) Q_{\mathrm{M}} \exp \left(-\lambda_{\mathrm{B}} T_{\mathrm{M}}\right)+(1-\beta) Q_{\mathrm{D}} \exp \left(-\lambda_{\mathrm{B}} T_{\mathrm{D}}\right)+(1-\gamma) Q_{\mathrm{S}} \exp \left(-\lambda_{\mathrm{B}} T_{\mathrm{S}}\right)+(1-\delta) Q_{\mathrm{C}}\left\{1-\exp \left(-\lambda_{\mathrm{B}} T_{\mathrm{C}}\right)\right\}}{(1-\varepsilon) M_{\mathrm{M}}+(1-\zeta) M_{\mathrm{D}}+(1-\eta) M_{\mathrm{S}}}
$$

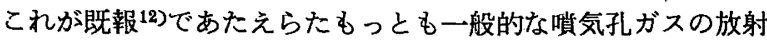
性成分含有量を表わす式である。

玉川温泉においては分子の第 1 項，第 2 項および第 4 項が，ま ったく無視できるかどうか問題である。ことに第 2 項および第 4 項は，玉川温泉の存在を考慮にいれて設けた項であるから，玉川 温泉のたとえば大ブキのように，演出量（ガス，温泉水とも）の 大きいものについては，一般的でないとしてまったくこの項を無 視することはできない。しかしいまとりあつかっている噴気孔 は，ガスの噴出だけがあるもので第 4 項に関係する温泉水の櫍出 量はきわめて小さい。また, トロンの含有量, ラドンの含有量, トロンとラドンの量比，いずれをみても，主川温泉櫴気孔群の主 流である大ブキよりるこの大ブキ No. 4 噴気孔のほうが大きい のであるも゙*?。とくにトロンの含有量は決定的に大きい。したが って大ブキ No. 4 のガスのラドン，トロンの供給帯を考えるか ぎりでは，さきの一般式の分子の第 1 項，第 2 項をむ無視し，ま た Qs をかきあらため

$$
\begin{gathered}
C_{\mathrm{N}}=K\left[\frac{Q_{\mathrm{BO}}}{M_{\mathrm{T}}}\right]=K\left[(1-\gamma) C_{\mathrm{SB} \max }\left\{1-\exp \left(-\lambda_{\mathrm{B}} t_{\mathrm{A}}\right)\right\} \exp \left(-\lambda_{\mathrm{B}} T_{\mathrm{S}}\right)\right] \\
\text { ただし } C_{\mathrm{SB} \max }=f\left(C_{\mathrm{A}}, S \text {, etc. }\right) \quad K=\text { 定数 }
\end{gathered}
$$

とするのが適当である。

ことに玉川温泉大ブキ No. 4 の付近にはラドン，トロンの供 給源となりうるものが，北投石として地表にみいだされているの である。

なお No. 4 の噴出点の湯川の底には，かなり厚いイオウ質沈 段物が沈殿している。このイオウ質沈殿物の中にもラジウム， ト リウムXを含む北投石の微結晶が存在する8)13144)。これらは浅い 供給帯そのものの一端とみることができる。

ただ箱根の場合1にくらべ，ラドン含有量，トロン含有量の変 化のしかたがまったく異なることをどう解积するかが問題であ る。

この噴気孔のある玉川温泉は強酸性泉で $\mathrm{Cl}^{-}>\mathrm{SO}_{4}{ }^{2-}$ であり， F- 含有量む大きく，運びだしている熱量もきわめて大きい。ま た焼山火山の山腹に位置しており，焼山火山性 1949〜1951 年に 小爆発を起している15)。温泉水の化学組成もかなり变化すること が知られており，活火山の山腹にあるという事情むあって，熱水の 量, ガスの量ともにかなり変化すること法えられる。しかしこ れは比較的長い周期をるって起ると考光られる変化*日であって, いま問題にしているのはるう少し短い周期の変化である。No. 4 の噴出状態を観察していると，ときどき変化することはまえにも ふれれたが, No. 4 の付近の湯川の底のイオウ質沈殿物の㕌には ところどころ穴があいている。これはときどきガスが䠣出する穴

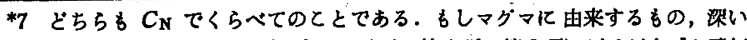

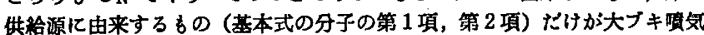
孔群のガスの放射性成分含有量を支配しているとすれば，大ブキのように鲐 出基の大きいるののトロン含有量, ラドン含有量などが, No. 4 より小さ いというととはありえない,大ブキのラドンなどは基本式の分子の第 4 項に 由来する可能生もあるてとを考えるとなねさらである.

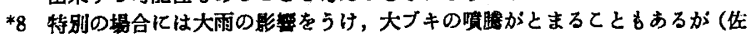
原，秋田大地下盗澺研 20，51 (1959))，著者のみた筑囲ではこのような異 常はみとめられなかった.

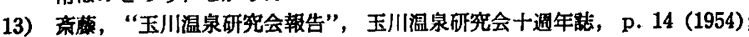

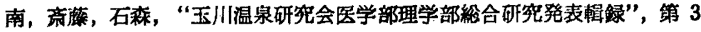
胡 p. 3 (1952).

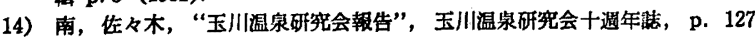
(1954).
で，事実ときどきそれが観察できる。すなわちガスの出口がとき どき変化するのである。あるいは地下に空洞のようなものがあっ て，ある程度ガスがたまってから噴出するということがあるかも 知れない。間ケツ泉がかってこの付近に存在していたというがも, まえに間ケツ泉が存在していたという環境，むしくは構造が一部 でも地下に残っているかも知れない。出口が変わることは，通路 がときどき変化するととを意味するのかも知れない。地下の構造 の複雑さは地下からくるガスと浅所地下水との関係をも複雑にす る。表 1 に明らかなように，この噴気孔ガスの R はときどき相当 大きく変化する。箱根大溥谷の賲気孔ガスの $\mathrm{R} か ゙$ 約 10 年の間あ まり変わっていないことと対照的である。いまの場合, 阿蘇楊, 谷温泉咆哮地獄間ケツ泉のガスの $\mathrm{R}$ とラドン含有量が，大体対応 して変化するように ${ }^{16)}, \mathrm{R}$ の大きいときにはラドン含有量が大き いという傾向がみえる('58.10.15 の例) が，しかしまったく逆に Rが 30\% であるのにラドン含有量がかなり小さいという例もあ り簡単ではない('54.10.3 の例)。

いま考えてきたことは

$$
C_{\mathrm{N}}=K\left[(1-\gamma) C_{\mathrm{SB} \max }\left\{1-\exp \left(-\lambda_{\mathrm{B}} t_{\mathrm{A}}\right)\right\} \exp \left(-\lambda_{\mathrm{B}} T_{\mathrm{S}}\right)\right]
$$

において, $\gamma, t_{\mathrm{A}}, T_{\mathrm{S}}$ ，および $C_{\mathrm{SB} \text { max }}$ をきめる $C_{\mathrm{A}}, S$ のうち $r, t_{\mathrm{A}}, T_{\mathrm{S}}$ が変わりや寸いということであった。そのうえ箱根大 湧谷の場合とちがう点は, $C_{\mathrm{A}}$ が供給带の各部分でちがう可能性 があることである。それは北投石のようにラジウム，トリウムX が特定の鉱物の中にはいったものが生成し，それが供給帯の中で 供給源として作用している点である。空間における, ラジウム, トリウム Xの分布状態からみると，たとえば岩石中にラジウム， トリウムXが分布しているのにくらべれば局所的, 集中的である といえよう。箱根で供給帯中のラジウム，トリウム $\mathrm{X}$ の分布状態 を分散的と推定したが，これは北投石のような放射性温泉沈殿物 が付近にみいだされないことを一つの根拠にして考えたのであっ た。これの反対のケースとして玉川の噴気孔群を考えたわけであ る。このように局所的, 集中的なラジウム,トリウム $\mathrm{X}$ の存在と, とおりみちの変化とが関係してくると, 変化の性格はますます襀 雑さを増すはずである。さらに，Sなどの変化もないとはいえな w。

こう考えてくると，临気孔ガスの放射性成分含有量，上くに短 寿命のトロンの含有量などは変化するのがむしろ当然のようにも 思われるが, すでに明らかにしたように箱根の例もあり, また次 報にのベる例むあって, 玉川温泉大ブキ No. 4 の例, 変化の傾 向が必ずしも一般的とは思われないようである*9。

玉川温泉大ブキ No. 4 の筫気孔ガスの多数の測定值のうち， これらの多数の変数が, 一つをのぞいて短時間にほぼ一定とみな しうるものはないかといろいろ吟味したが，めぼしい䙺則性をみ いだすととができなかった。

ただ噴出状態の変化がはげしく，放射性成分含有量の变化がい ちじるしいといっても，1952年以来哄気孔の性質がしだいに変わ り,とくに 1955 年以降この噴気孔の嘪出状態は比較的弱くまた 定常的になり, トロン含有量, ラドン含有量の变化も, それほど

15）津屋，“玉川温泉研究会悕告”，玉川温泉研究会十週年娟，p. 130 (1954). 16) 岩崎, 桂, 小沢, 吉田, 錐田, 松本, 日本火山学会秋季大会渋演 (1958).

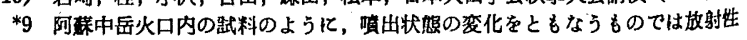
成分含有量が変化するてとはいうまでもない. 
大きいものではなくなってきた。

さき考えたように，それ以前はしばしば変わっていた諸条件 があまり変わらなくなったのかも知れない。ただし， R とラドン 含有量との関係には注意する必要があり，1958 年 10 月 15 日の 例のようにRがきわめて大きくなりラドン含有量がいちじるしく 大きくなった例がある。

考察のはじめにおいて, トロンの変化の幅が, ラドンの変化の 蝠よりいくらか大きいことを指摘したがこれは半減期の差から当 然と考号られる。また $\mathrm{Tn} / \mathrm{Rn}$ の変化の幅がいくらか小さいの は，rがこの比を取れば消え，影響しなくなるためであろう。 R の変化にともなった䠝出時のラドン, トロンの含有量の変化があ る場合には，Tn/Rn を考えればまえと変わらないはずである。

放射能泉においては降雨の影響が温泉水のラドン含有量にあら われるとよくいわれるが228)5)，噴気孔ガスの場合には，地表水の 影響をうけて地下からの噴気孔ガス中の可溶性の酸性ガスがガス 中から失なわれ，Rが増大し，それにとむなって水に対する溶解度 の小さなラドン，トロンのガス中の含有量が相対的に増加する可 能性が考えられる。1958 年 10 月 15 日の測定はこれを示してい る。しかしほかに複雑な要因があるためか，1954 年 10 月 10 日 の測定例のように降雨後 Rがいちじるしく大きくなりながらラド ン含有量があまりふえない例もある。少なくとも，湧出量の比較 的少ない, 温度む低い強放射能泉で, 降雨後にラドン含有量が異 常に大きくなる現象はあまりみいだしえない。これは，低温の浻 出量も少ない温泉水とちがい, 貲出量も大きく, 温度も高い噴気 孔ガスにおいては, 地表面のぬれの影響があまりないことを意味 するものであろう。

\section{5 結論}

火山性強酸性泉であり，放射性温泉沈殿物を産出するので有名 な，秋田県玉川温泉の一唄気孔ガスについて，1952年以降，その
放射性成分含有量を研究してつぎの結果をえた。

1. この噴気孔ガスのトロン含有量が 本邦での 最大級の 值を 示した。最高值 $22300 \times 10^{-10} \mathrm{curie} \mathrm{Tn} / l$ (NTP, $\mathrm{H}_{2} \mathrm{O}$ をのぞ く)。

2. この噴気孔ガス中のトロンとラドンの量比は, 本邦での最 大級の值を示した。すなわち curie 比で最高 490 , 小さいときで も 35 ぐらいの值をしめす。

3. ラドン含有量, トロン含有量の変化, トロンとラドンの量 比の変化がはぼしい。

これらの結果をいろいろ吟味して，これらのラドン,トロンは， その大部分务地表括よび地下比較的浅所にあるラドン，トロンの 供給帯から供給されるもので，供給帯中におけるラジム，トリ ウム $\mathrm{X}$ の局所的, 集中的な分布状態と，この貲気孔の噴出状態が 変化しやすいことから, トロン含有量, ラドン含有量, あるいは 量比にいちじるしい変化がおこることを結論した。

供給帯が地表からごく近いために，トロン含有量，トロンとラ ドンの量比はきわめて大きい值を示す。

このような供給帯の生成が火山作用と関係があるかどうかは, 今後なお慎重に検討する必要がある。

終りにのぞみ，終始御指導をいただいた岩崎岩次博士にあつく 御礼申しあげる。な扰本研究の遂行にあたっては, 桂 敬博士, 下島 光, 小沢竹二郎, 吉田 稔, 平山光衛, 岩崎交解, 松本幡 郎の諸氏, また原村 寛氏らの熱心な御協力をえた。あわせて厚 く感謝する。

また本研究は，南 英一博士ほか多くの研究者とともに，玉川 温泉研究会の御支援をえて行なったものである。同会の各位，と くに海野 精氏に厚く御礼申しあげる。

研究に要した費用の一部は文部省科学研究費交付金をもって支 弁した。

（1953 年，地球化学討論会（一部）請演）

\section{栗野岳温泉噴気孔ガスの放射性成分含有量*1}

（将和 36 和 1 月 24 日受理）

鎌田政明†

鹤島火山西北端の栗野岳温泉の貲気孔ガスについて 1950 年以来その放射性成分含有量を調査した。その結果てての噴気孔ガス の放射性成分含有㻎はかなり大きいとと，㵒出势力の強大なもののラドン含有量が一般に小さく，償出势力の弱いものがかえって ラドン含有惶が大きいとと，Tn/Rn は磺出勢力と正の相関をもっているととを知った。

とくに注目すべきととは，放射性成分含有量の変化の幅が比較的小さいてとで, Tn/Rn の比をとるとさらにとの傾向がはっき りする。前ノ湯 No. 2 噴気孔ガスの Tn/Rnは，数年間にわたってはとんど変化していない。ての性質は玉川温泉大ブキNo.4 噴気孔ガスのそれとまったく対照的である。玉川温泉の北投石に相当する放射性温泉沈殿物はての地域の地表付近にはみあたらな い。

てのような性質から，乙の櫍気孔群のガスの放射性成分も，箱根の場合と同じうに，比較的浅いところにある供給帯から供給 されるもので，供給帶中のラシシウム，トリウムXの分布は比較的分散的であろうと推定した。

\section{1 緒言} 前報》で，秋田県玉川温泉大ブキの一噴気孔ガスのラドン含有

*1 との報文を “本邦火山の地球化学的研究（その 46）喷気孔ガスの故射制成 分 (第 6 報)”とする。
量,およびトロン含有量がきわめて変化しやすいてとを報告した。 そして箱根大湧谷の例2〕参考として，このような性質は一般の

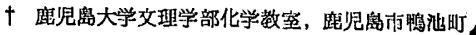

1）前䇉（第 5 報），鎌田，日化 82，1143 (1961)

2) 鎌田, 日化 82, 1008 (1961).
} 